\title{
Downstream variations in the width of bedrock channels
}

\author{
David R. Montgomery and Karen B. Gran \\ Department of Geological Sciences, University of Washington, Seattle, Washington
}

\begin{abstract}
Field surveys of channel width $w$ and drainage area $A$ in bedrock channel reaches reveal relationships where $w=c A^{b}$, similar to the classic hydraulic geometry of alluvial channels. Data from five mountain channel networks support the assumption used in many landscape evolution models that an alluvial hydraulic geometry relationship where $b=0.3-0.5$ holds for bedrock channel systems. Although there is substantial local variability in channel width in bedrock channel systems, there is no systematic difference in width versus drainage area relations for the surveyed bedrock and alluvial reaches in sedimentary lithologies in coastal Oregon and Washington. In contrast, bedrock channels were narrower, and therefore had deeper flow, than alluvial channels with equal drainage areas in the granite and limestone terrain of the Yuba River, California. In addition, data from the Mokelumne River show that bedrock channel width decreases substantially downstream at the contact between relatively weak limestone and more erosion-resistant granite, but that channel slope does not change appreciably across contacts between these two lithologies. Data from coastal Oregon drainage basins further show systematic channel widening after flood flows and debris flow impacts. We conclude that downstream variations in the width of bedrock channels generally follow traditional hydraulic geometry relations but also reflect the local influence of longitudinal patterns of bedrock erosivity and disturbance history.
\end{abstract}

\section{Introduction}

Recent interest in feedback between erosion and rock uplift, such as that between rates of river incision into bedrock, relief development, and hillslope stability [Schmidt and Montgomery, 1995; Burbank et al., 1996], has focused renewed attention on processes of bedrock river incision. This current interest in mountain rivers highlights how classic concepts and empiricisms of fluvial geomorphology are founded on studies of alluvial channel systems [Leopold et al., 1964]. Research on bedrock channels has addressed their morphology [Miller, 1991a; Wohl, 1992b, 1998, 1999] and distribution [Montgomery et al., 1996; Montgomery and Buffington, 1997; Massong and Montgomery, 2000], as well as processes that contribute to bedrock river incision [Foley, 1980; Miller, 1991b; Seidl and Dietrich, 1992; Wohl, 1992a; Wohl et al., 1994; Hancock et al., 1998; Whipple et al., 2000], but there is little work on how the geometry of bedrock channels scales with drainage basin size. Substantial local variations in channel width and unit stream power occur along bedrock channels [Wohl, 1992b], and it is not clear to what degree conventional hydraulic geometry relationships hold in such channels [Tinkler and Wohl, 1998]. Yet landscape evolution models increasingly incorporate assumptions about how bedrock channel geometry scales with basin size into studies of landscape evolution that link fluvial geomorphology and tectonic processes [Tucker and Slingerland, 1994; Whipple and Tucker, 1999].

Different erosional processes can be parameterized in different ways, but the popular unit stream power model for predicting bedrock erosion rates explicitly incorporates the role of downstream changes in channel width. Unit stream power is the product of the unit weight of water $\rho$, the dis-

Copyright 2001 by the American Geophysical Union.

Paper number 2000WR900393.

0043-1397/01/2000WR900393\$09.00 charge per unit channel width $Q / w$, and the channel slope $S$. Hence the bedrock incision rate $E$ as driven by unit stream power may be expressed as

$$
E \propto \rho g(Q / w) S .
$$

Classic hydraulic geometry relations show that channel width generally varies as a function of downstream changes in discharge:

$$
w=c_{1} Q^{b}
$$

where $c$ and $b$ are empirical exponents. Assuming a simple linear relation between discharge and drainage area $(Q=$ $c_{2} A$ ) allows recasting of (2) in a manner that can be readily analyzed from digital elevation models (DEMs):

$$
w=c_{3} A^{b} .
$$

Substitution of (3) into (1) then yields

$$
E=K A^{(1-b)} S,
$$

where $K$ incorporates the effects of bedrock erodibility and the other constants in (1)-(3). Even though it is not clear what exponent to use for incision of bedrock channels, as existing empirical relations are derived from alluvial channels, most landscape evolution models now assume that $b=0.5$ [Rodriguez-Iturbe and Rinaldo, 1997].

Here we report data on channel width versus drainage area from field surveys of mountain channels in Oregon, Washington, and California. The analysis draws on data from alluvial and bedrock reaches of six mountain drainage basins and explores implications for the parameterization of landscape evolution models.

\section{Previous Work}

Two different types of bedrock channels have been recognized in the geomorphological literature. In a broad sense, 
mountain channels in general are bedrock channels, as incision into bedrock is required to maintain their gradients over geologic time, even if they have a bed of alluvial material during periods between the high-discharge events that expose and erode rock. Consequently, channel networks in mountain drainage basins may be considered bedrock channel systems. Within bedrock channel systems some, if not most, reaches will have beds composed of alluvium, some may have bare bedrock beds, and others will have a mixed morphology of alternating alluvial and bedrock beds [Howard, 1980; Howard et al., 1994; Montgomery et al., 1996; Montgomery and Buffington, 1997]. Hence we may consider bedrock channels at the scale of either discrete channel reaches or entire channel systems that essentially encompass mountain channel networks [Montgomery and Buffington, 1998].

Relations with the general form of (2) have been found in studies of both canals and natural rivers. In early studies, Lacy [1929] reported that $b=0.5$ for stable canals, and Schoklitch [1937] reported that $b=0.6$ for natural rivers. Leopold and Maddock [1953] defined general downstream hydraulic geometry relations and found that $b=0.5$ for alluvial channels. Shortly thereafter, Leopold and Miller [1956] found that $b=$ 0.5 for ephemeral channels in New Mexico, and Wolman [1955] found that $b=0.57$ in his classic study of Brandywine Creek, Pennsylvania. Knighton [1998, p. 171] recently reviewed subsequent studies and concluded that the accumulated data "support the oft-quoted opinion that width varies approximately as the square root of discharge." Whether this generality extends to bedrock channels is unclear [Tinkler and Wohl, 1998], in part because few data have been reported for bedrock channel reaches in mountain drainage basins.

\section{Study Areas and Methods}

The present study draws upon both new field surveys and data collected in the course of previous studies of the distribution of bedrock and alluvial channel reaches in forested mountain drainage basins [Montgomery et al., 1996; Montgomery and Buffington, 1997; Massong and Montgomery, 2000]. Montgomery et al. [1996] surveyed reaches of the West Fork Satsop River and tributaries, and of these, 29 alluvial reaches and 18 bedrock reaches were appropriate for consideration here. Montgomery and Buffington [1997] reported data on the distribution, morphology, and bed form characteristics of various alluvial and bedrock reaches in mountain channel systems in Washington and Oregon. Although most of the systems they studied had very few bedrock reaches, enough bedrock reaches were mapped in Sullivan and Larson Creeks to analyze scaling differences between alluvial and bedrock reach widths. In addition, we analyze data for bedrock and alluvial reaches studied by Massong and Montgomery [2000] in the drainage basin of the Willapa River in southwestern Washington. The analysis presented here uses only the channel width data from the free-formed alluvial and bedrock reaches surveyed in these previous studies. We do not include data from reaches where logjams forced an alluvial morphology. Details of the study areas are included in the prior publications referred to above.

Additional field surveys of channel type and width were conducted in summer 2000 in Knowles Creek in the Oregon Coast Range, and in the Yuba and Mokelumne Rivers in the Sierra Nevada of California. In summer 2000 we also resurveyed channel widths in Sullivan and Larson Creeks, as the storm of record in November 1996 triggered extensive erosion by debris flows in these catchments after our first surveys.

Examination of the relationship between $W$ and $Q$ (or $A$ ) requires defining a reference discharge. For alluvial channels the reference discharge is typically considered that coincident with the bank-full stage. Although there is little in the way of definitive field criteria to guide selection of a bank-full depth (or any other reference depth) in many bedrock channels, the width of most bedrock channels can be more readily defined on the basis of the zone of active scour, as indicated by the limit of established perennial vegetation. Therefore we examine only the relation between channel width and drainage area, as they are relatively unambiguous to determine even for bedrock reaches. In all of the study areas the drainage area contributing to each reach was determined from mapping onto 1:24,000 scale topographic maps, and active channel widths were measured with a tape to the nearest $0.1 \mathrm{~m}$. Reach-average channel widths were determined as the mean of individual measurements within a reach, which ranged from a single measurement in small or morphologically simple reaches to as many as 10 measurements in large or complex channels. Although the data reported here differ from the classic hydraulic geometry based on discharge, the use of drainage area does present data in the format incorporated in most landscape evolution models.

\section{Results}

Relations between channel width and drainage area exhibit positive power function relations of the form $w=c A^{b}$ for both bedrock and alluvial reaches in the studied drainage basins (Figure 1). Data from bedrock reaches plot within the scatter of the data from alluvial reaches, and differences between the regression coefficients for bedrock and alluvial reaches were not significant for the Satsop and Willapa Rivers and Sullivan and Larson Creeks. Both the bedrock and alluvial reaches from the Satsop River and the pre-1996 Sullivan and Larson Creek data exhibit relations where $b \approx 0.5$, whereas the Willapa River and the resurveyed Sullivan and Larson Creek data exhibit $b=0.32-0.42$ (Table 1 ).

In contrast to the other study areas, alluvial reach data from the Yuba River plot at the upper end of data from bedrock reaches with similar drainage area. Although the difference in $b$ values of 0.37 and 0.45 from bedrock and alluvial reaches on the Yuba River was not significant, the difference between $c$ values was significant $(p<0.001)$. The ratio of the $c$ values indicates that alluvial reaches tend to be more than twice as wide as bedrock reaches along the Yuba River.

The data from Knowles Creek show an interesting difference in the relation between bedrock and alluvial channel widths for reaches with drainage areas greater than or less than $1 \mathrm{~km}^{2}$. For those basins larger than $1 \mathrm{~km}^{2}$ the widths of alluvial and bedrock reaches are indistinguishable, with no significant difference between either the $c$ values or the respective $b$ values of 0.53 and 0.32 . For those basins smaller than $1 \mathrm{~km}^{2}$, bedrock reach widths plot above data from alluvial reaches. The $c$ values for these bedrock reaches were significantly greater than those of alluvial reaches, although the difference in respective $b$ values is not significant. Field observations in these headwater channels indicate that these anomalously wide bedrock reaches had been scoured recently by debris flows.

The resurvey of Larson and Sullivan Creeks revealed a wider channel system than was documented in our original surveys. Despite the relatively small sample size the difference in the 

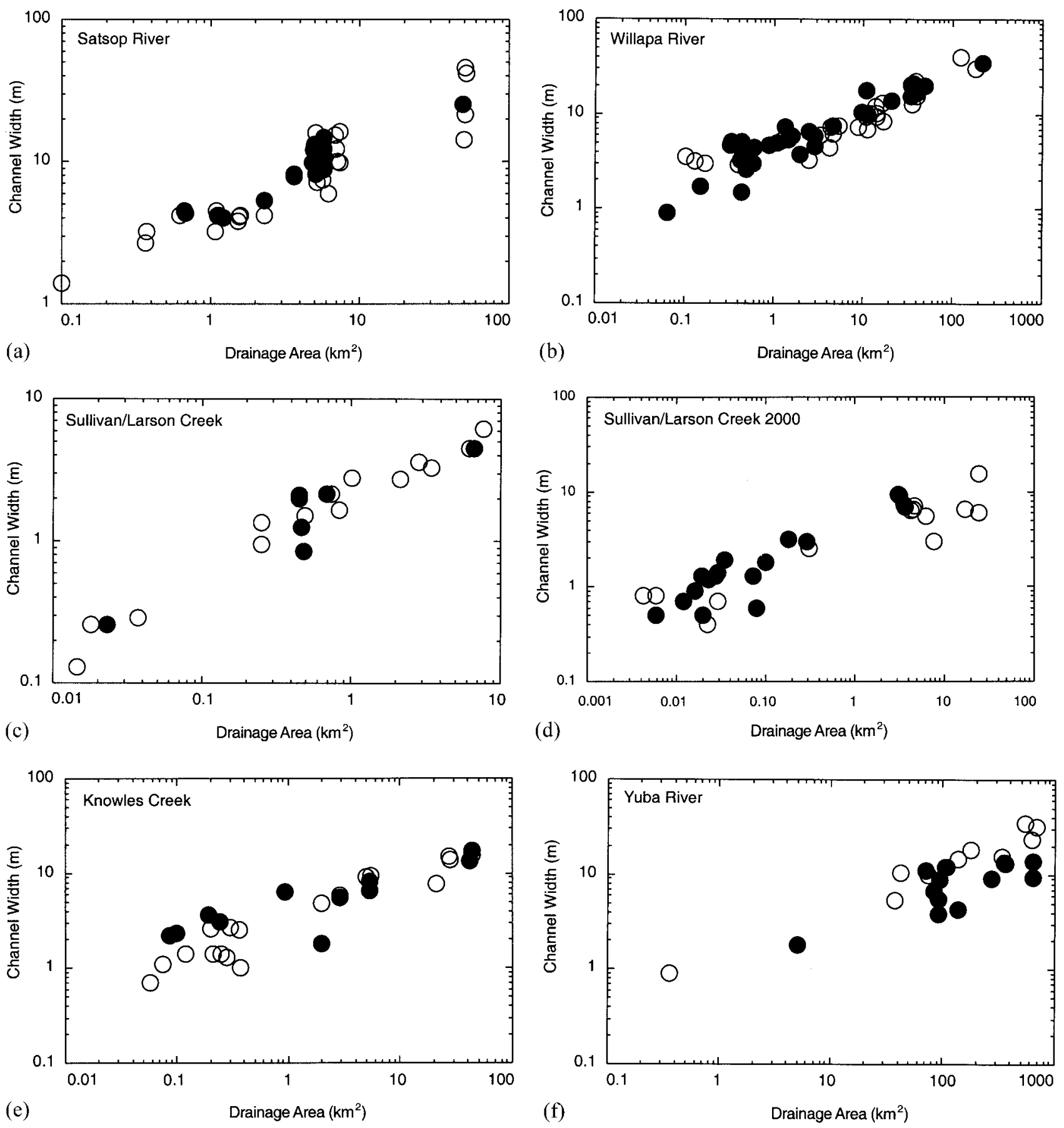

Figure 1. Channel width versus drainage area for bedrock and alluvial reaches in (a) Satsop River, Washington, (b) Willapa River, Washington, (c) 1993-1995 data for Sullivan and Larson Creeks, Oregon, (d) 2000 data for Sullivan and Larson Creeks, Oregon, (e) Knowles Creek, Oregon, and (f) Yuba River, California. Bedrock reaches are shown as solid circles; alluvial reaches are shown as open circles.

composite $b$ values from the pre- and post-1996 storm data is significant $(p<0.001)$. Although the significant difference in regression slopes precludes a direct test of differences in $c$ values, the reach widths measured in our summer 2000 surveys were systematically wider than those documented in our earlier surveys (Figure 2). The November 1996 storm was the storm of record, delivering $16 \mathrm{~cm}$ of rainfall in a 24-hour period and triggering numerous landslides in the area [Montgomery et al., 2000], several of which resulted in debris flows that scoured portions of Sullivan Creek. The systematic channel widening revealed by our resurvey reflects both local bank erosion and expansion of the active bed width defined by the zone of scour in locations where bedrock channel banks are ill defined. We lack the repeated cross-section surveys needed to sort out the relative contribution of these processes to the observed channel widening.

Overall, the exponent in width-drainage area relations ranges from $0.30 \pm 0.08$ to $0.53 \pm 0.14$ for bedrock reaches and from $0.32 \pm 0.07$ to $0.55 \pm 0.03$ for alluvial reaches of these bedrock channel systems. Although the relationships reported 
Table 1. Hydraulic Geometry Relations for the Studied Mountain Drainage Basins ( $w=$ $\left.c A^{b}\right)$

\begin{tabular}{|c|c|c|c|c|}
\hline Study Area & $c^{\mathrm{a}}$ & $b$ & $R^{2}$ & $n$ \\
\hline \multicolumn{5}{|l|}{ Satsop River } \\
\hline Bedrock reaches & 0.007 & $0.47 \pm 0.05$ & 0.87 & 18 \\
\hline Alluvial reaches & 0.005 & $0.49 \pm 0.04$ & 0.85 & 29 \\
\hline \multicolumn{5}{|l|}{ Willapa River } \\
\hline Bedrock reaches & 0.054 & $0.32 \pm 0.02$ & 0.83 & 26 \\
\hline Alluvial reaches & 0.020 & $0.39 \pm 0.03$ & 0.86 & 40 \\
\hline \multicolumn{5}{|c|}{ Sullivan and Larson Creeks } \\
\hline Bedrock reaches & 0.002 & $0.51 \pm 0.09$ & 0.86 & 7 \\
\hline Alluvial reaches & 0.001 & $0.55 \pm 0.03$ & 0.97 & 14 \\
\hline \multicolumn{5}{|c|}{ Sullivan and Larson Creeks (2000) } \\
\hline Bedrock reaches & 0.015 & $0.42 \pm 0.04$ & 0.86 & 18 \\
\hline Alluvial reaches & 0.034 & $0.33 \pm 0.04$ & 0.86 & 13 \\
\hline \multicolumn{5}{|l|}{ Knowles Creek $>1 \mathrm{~km}^{2}$} \\
\hline Bedrock reaches & 0.002 & $0.53 \pm 0.14$ & 0.78 & 5 \\
\hline Alluvial reaches & 0.050 & $0.32 \pm 0.07$ & 0.77 & 8 \\
\hline \multicolumn{5}{|l|}{ Knowles Creek $<1 \mathrm{~km}^{2}$} \\
\hline Bedrock reaches & 0.088 & $0.30 \pm 0.08$ & 0.71 & 7 \\
\hline Alluvial reaches & 0.012 & $0.40 \pm 0.20$ & 0.33 & 10 \\
\hline \multicolumn{5}{|l|}{ Yuba River } \\
\hline Bedrock reaches & 0.008 & $0.37 \pm 0.09$ & 0.60 & 12 \\
\hline Alluvial reaches & 0.003 & $0.45 \pm 0.04$ & 0.93 & 12 \\
\hline
\end{tabular}

${ }^{\text {aThe }} c$ values are reported for channel width in meters, and drainage area is reported in square meters. The $n$ values are the total number of observations in each regression. $P$ values for all regressions were $<0.01$.

here are derived from relatively small data sets, they do illustrate a general consistency of the observed relationships with the form of (3).

We did not collect data across a wide enough range of drainage areas to evaluate $b$ values for the Mokelumne River. We did, however, find an interesting pattern of variations in channel width at a location where we were able to access the channel along a 5-km-long reach (Figure 3). At the upstream end of this reach the 30-m-wide channel flows over limestone. Over the next $2 \mathrm{~km}$ downstream the channel widens to $47 \mathrm{~m}$ before it crosses a geologic contact to flow over granite. Downstream of the contact the channel abruptly narrows to $15 \mathrm{~m}$ and then widens to almost $25 \mathrm{~m}$ by the end of our survey. Hence a systematic downstream increase in channel width can be reset by strong lithologic contrasts, such as that between relatively weak limestone and hard Sierran granite.

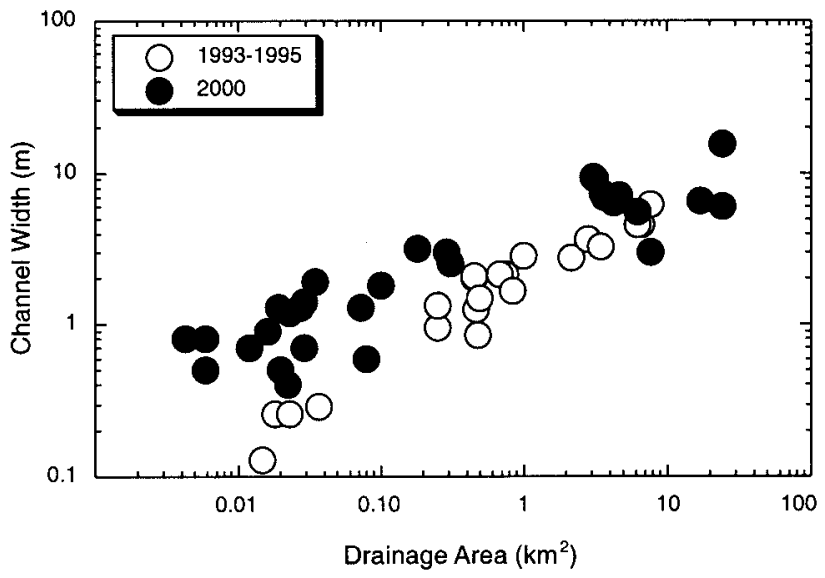

Figure 2. Channel width versus drainage area for surveyed reaches in Sullivan and Larson Creeks from 1993-1995 and summer 2000.

\section{Discussion}

The range in $b$ values of $0.3-0.5$ for bedrock channels is broader than that for the classic discharge-width relation for alluvial channels (i.e., $b=0.5$ ), although within most of the study basins there is no discernible difference in the relations for bedrock and alluvial reaches. While two of the data sets support using $b \approx 0.5$ in models for bedrock river incision based on unit stream power calculated from DEMs, four data sets support using $b$ values between 0.3 and 0.45 . Part of this difference may lie in the conversion of $Q$ into $A$, as a nonlinear relation would affect the exponent in the drainage area-width relation. Unfortunately, data on the downstream relation between discharge and drainage area are not available for these channels.

Three of our data sets with $b=0.3-0.45$, the Willapa River, the Knowles Creek data from basins with drainage areas $<1 \mathrm{~km}^{2}$, and the resurveyed data from Sullivan and Larson Creeks, were heavily impacted by recent debris flows. Perhaps

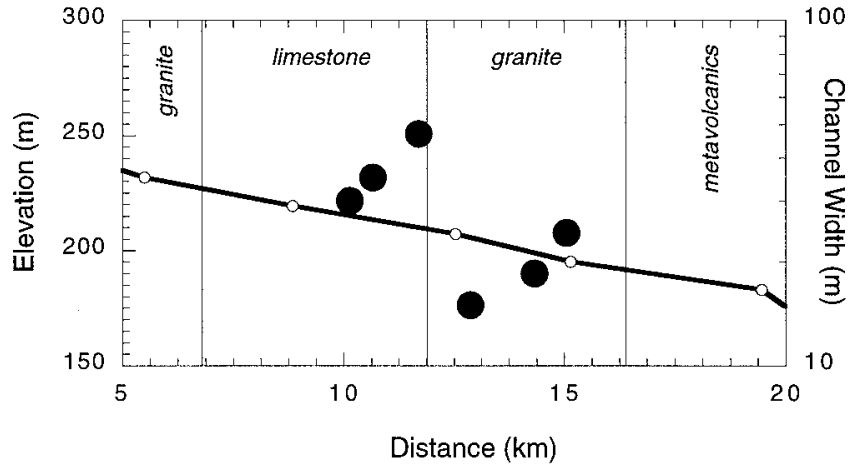

Figure 3. Channel width versus distance downstream for a 5-km-long reach of the Mokulmne River, California. Geologic contacts are indicated by vertical lines. 


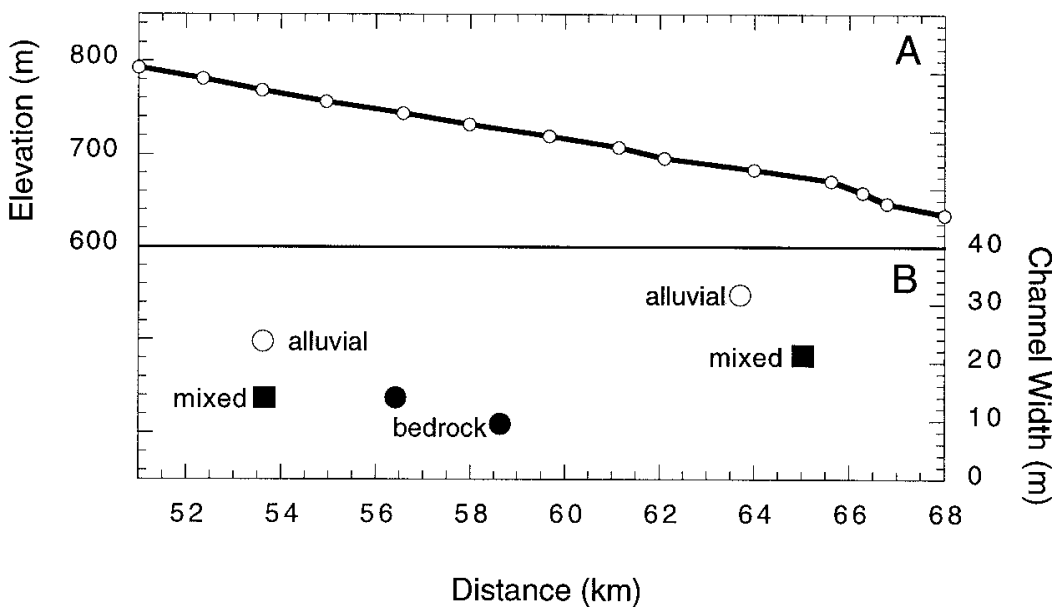

Figure 4. (a) Long profile and (b) variations in channel width and type along a portion of the Yuba River, California.

serendipitously, the $b$ value for the Sullivan and Larson Creek data changed from $\sim 0.5$ to 0.3 to 0.4 after the storm of record in which debris flows impacted the channels. Although it is not clear to what extent debris flow processes influence downstream variation in channel width, the relative influence of the associated scour would be expected to decrease downstream, an expectation consistent with a shift to lower $b$ values after debris flow-related disturbance.

Montgomery and Buffington [1997] found that bedrock channels occur at higher shear stress than do alluvial reaches, which could result from either deeper flow or steeper slopes. In support of the latter mechanism, Montgomery et al. [1996] showed that bedrock reaches along the Satsop River occurred where local channel slopes were steep for the drainage area of the channel. In contrast, reach slope does not change appreciably along a stretch of the Yuba River where channel width varies from 10 to $35 \mathrm{~m}$, with alluvial reaches having the greatest widths, bedrock reaches having the narrowest widths, and mixed morphology reaches having intermediate widths (Figure 4). Recall that in the Yuba River data, alluvial reaches were consistently wider than bedrock reaches with the same drainage area, implying shallower flow for comparable discharges. In combination with data from prior studies this shows that variations in both channel width (and thereby flow depth) and slope influence the distribution of bedrock and alluvial channel reaches.

The evidence for differences in channel slope and width as controls on bedrock channel distribution in different basins leads us to hypothesize that in drainage basins with relatively uniform lithology, variations in channel slope primarily control the distribution of bedrock reaches, whereas in basins with highly variable rock strength, such as in the Yuba and Mokulmne Rivers, variations in channel width can adjust the shear stress on the bed to equalize the erosion rate without variations in channel slope. Note, however, that the data examined here do not include deeply incised canyons, which can have large changes in channel width due to undulations in the valley walls [Wohl et al., 1999].

Our data for the downstream scaling of bedrock channel geometry suggests that bedrock channels share some elements of the hydraulic geometry of alluvial channels. We also find evidence for a lithologic influence on bedrock channel widths, unlike the self-formed architecture of alluvial channels. In addition, we find that the width of bedrock channels can vary temporally, with the size of the last flood event influencing the apparent channel width. Further investigations of variations in the width of bedrock channels are needed to assess the generality of our findings and to enhance our understanding of local influences on the width of mountain channels.

Acknowledgments. We thank Suzanne C. S. Hawley, Tim Abbe, John Buffington, Tamara Massong, Kevin Schmidt, and Jonathan Stock for helping to collect the data analyzed here and Keith Tinkler and Ellen Wohl for prompting us to analyze data collected for other purposes. We also thank Gordon Grant, Ellen Wohl, Alan Howard, and Tom Lisle for their constructive critiques of the manuscript.

\section{References}

Burbank, D. W., J. Leland, E. Fielding, R. S. Anderson, N. Brozovic, M. R. Reid, and C. Duncan, Bedrock incision, rock uplift and threshold hillslopes in the northwestern Himalayas, Nature, 379, 505-510, 1996.

Foley, M. G., Bed-rock incision by streams, Geol. Soc. Am. Bull., Part 2, 91, 2189-2213, 1980.

Hancock, G. S., R. S. Anderson, and K. X. Whipple, Beyond power: Bedrock river incision process and form, in Rivers Over Rock: Fluvial Processes in Bedrock Channels, Geophys. Monogr. Ser., vol. 107, edited by K. Tinkler and E. Wohl, pp. 35-60, AGU, Washington, D. C., 1998.

Howard, A. D., Thresholds in river regime, in Thresholds in Geomorphology, edited by D. R. Coates and J. D. Vitek, pp. 227-258, Allen and Unwin, Concord, Mass., 1980.

Howard, A. D., W. E. Dietrich, and M. A. Seidl, Modeling fluvial erosion on regional to continental scales, J. Geophys. Res., 99, 13,971-13,986, 1994.

Knighton, D., Fluvial Forms and Processes, Edward Arnold, London, 1998

Lacy, C., Stable channels in alluvium, Proc. Inst. Civ. Eng., 229, 259384, 1929

Leopold, L. B., and Maddock, T., The hydraulic geometry of stream channels and some physiographic implications, U.S. Geol. Surv. Prof. Pap., 252, 57 pp., 1953.

Leopold, L. B., and J. P. Miller, Ephemeral streams: Hydraulic factors and their relation to the drainage net, U.S. Geol. Surv. Prof. Pap., 282-A, 37 pp., 1956.

Leopold, L. B., M. G. Wolman, and J. P. Miller, Fluvial Processes in Geomorphology, W. H. Freeman, New York, 1964.

Massong, T. M., and D. R. Montgomery, Influence of lithology, sediment supply, and wood debris on the distribution of bedrock and alluvial channels, Geol. Soc. Am. Bull., 112, 591-599, 2000.

Miller, J. R., Controls on channel form along bedrock-influenced al- 
luvial streams in south-central Indiana, Phys. Geogr., 12, 167-186, 1991a.

Miller, J. R., The influence of bedrock geology on knickpoint development and channel-bed degradation along downcutting streams in south-central Indiana, J. Geol., 99, 591-605, 1991b.

Montgomery, D. R., and J. M. Buffington, Channel reach morphology in mountain drainage basins, Geol. Soc. Am. Bull., 109, 596-611, 1997.

Montgomery, D. R., and J. M. Buffington, Channel processes, classification, and response potential, in River Ecology and Management, edited by R. J. Naiman and R. E. Bilby, pp. 13-42, Springer-Verlag, New York, 1998.

Montgomery, D. R., T. B. Abbe, N. P. Peterson, J. M. Buffington, K. M. Schmidt, and J. D. Stock, Distribution of bedrock and alluvial channels in forested mountain drainage basins, Nature, 381, 587589, 1996.

Montgomery, D. R., K. M. Schmidt, H. Greenberg, and W. E. Dietrich, Forest clearing and regional landsliding, Geology, 28, 311-314, 2000

Rodriguez-Iturbe, I., and A. Rinaldo, Fractal River Basins: Chance and Self-Organization, 547 pp., Cambridge Univ. Press, New York, 1997.

Schmidt, K. M., and D. R. Montgomery, Limits to relief, Science, 270 , 617-620, 1995.

Schoklitch, A., Hydraulic Structures, vol. 1, 488 pp., Am. Soc. of Mech. Eng., New York, 1937.

Seidl, M. A., and W. E. Dietrich, The problem of channel erosion into bedrock, Catena Suppl., 23, 101-124, 1992.

Tinkler, K., and E. Wohl, A primer on bedrock channels, in Rivers Over Rock: Fluvial Processes in Bedrock Channels, Geophys. Monogr. Ser., vol. 107, edited by K. Tinkler and E. Wohl, pp. 1-18, AGU, Washington, D. C., 1998.

Tucker, G. E., and R. L. Slingerland, Erosional dynamics, flexural isostasy, and long-lived escarpments: A numerical modeling study, $J$. Geophys. Res., 99, 12,229-12,243, 1994.
Whipple, K. X., and G. E. Tucker, Dynamics of the stream-power river incision model: Implications for height limits of mountain ranges, landscape response time scales, and research needs, J. Geophys. Res., 104, 17,661-17,674, 1999.

Whipple, K. X., G. S. Hancock, and R. S. Anderson, River incision into bedrock: Mechanics and relative efficacy of plucking, abrasion, and cavitation, Geol. Soc. Am. Bull., 112, 490-503, 2000.

Wohl, E. E., Gradient irregularity in the Herbert Gorge of northeastern Australia, Earth Surf. Processes Landforms, 17, 69-84, 1992a.

Wohl, E. E., Bedrock benches and boulder bars: Floods in the Burdekin Gorge of Australia, Geol. Soc. Am. Bull., 104, 770-778, 1992b.

Wohl, E. E., Bedrock channel morphology in relation to erosional processes, in Rivers Over Rock: Fluvial Processes in Bedrock Channels, Geophys. Monogr. Ser., vol. 107, edited by K. Tinkler and E. Wohl, pp. 133-151, AGU, Washington, D. C., 1998.

Wohl, E. E., Incised bedrock channels, in Incised River Channels, edited by S. E. Darby and A. Simon, pp. 187-217, John Wiley, New York, 1999.

Wohl, E. E., N. Greenbaum, A. P. Schick, and V. R. Baker, Controls on bedrock channel incision along Nahal Paran, Israel, Earth Surf. Processes Landforms, 19, 1-13, 1994.

Wohl, E. E., D. M. Thompson, and A. J. Miller, Canyons with undulating walls, Geol. Soc. Am. Bull., 111, 949-959, 1999.

Wolman, M. G., The natural channel of Brandywine Creek, Pennsylvania, U.S. Geol. Surv. Prof. Pap., 271, 56 pp., 1955.

K. B. Gran and D. R. Montgomery, Department of Geological Sciences, University of Washington, Box 351310, Seattle, WA 98195 1310. (kbgran@u.washington.edu; dave@geology.washington.edu)

(Received April 18, 2000; revised December 1, 2000; accepted December 1, 2000.) 